\section{Regards sur l'économie allemande}

Bulletin économique du CIRAC

$103 \mid 2011$

Varia

\title{
Secteur ferroviaire
}

HELMSTÄDTER F., Die Trennung von Netz und Betrieb im

Eisenbahnsektor. Eine europarechtliche Untersuchung des Ownership Unbundling

\section{(2) OpenEdition}

1 Journals

Édition électronique

URL : http://journals.openedition.org/rea/4371

DOI : 10.4000/rea.4371

ISBN : 978-2-8218-1136-2

ISSN : 1965-0787

Éditeur

CIRAC

Édition imprimée

Date de publication : 16 décembre 2011

ISSN : 1156-8992

\section{Référence électronique}

"Secteur ferroviaire », Regards sur l'économie allemande [En ligne], 103 | décembre 2011, mis en ligne le 20 décembre 2011, consulté le 22 septembre 2020. URL : http://journals.openedition.org/rea/4371 ; DOI : https://doi.org/10.4000/rea.4371

Ce document a été généré automatiquement le 22 septembre 2020.

(c) CIRAC 


\section{Secteur ferroviaire}

HELMSTÄDTER F., Die Trennung von Netz und Betrieb im

Eisenbahnsektor. Eine europarechtliche Untersuchung des Ownership

Unbundling

\section{RÉFÉRENCE}

HELMSTÄDTER F., Die Trennung von Netz und Betrieb im Eisenbahnsektor. Eine europarechtliche Untersuchung des Ownership Unbundling, Coll. EWERK, vol. 43, Nomos Verlag, Baden-Baden, 2011, 356 p.

1 Cette thèse de doctorat analyse, sous l'angle du droit européen, la question actuelle cruciale (et hautement délicate) de la séparation entre les activités de gestion des réseaux ferroviaires et l'exploitation commerciale des services de transport dans le contexte de l'ouverture du marché. Sa liste bibliographique est arrêtée fin décembre 2010. (ib) 